\title{
Research on Reasonability of the Use of a New Liquid-Phase Biological Product in Different Soils
}

\author{
G. Yu. Rabinovich ${ }^{1}$, N. G. Kovalev ${ }^{1}$ \& Yu. D. Smirnova ${ }^{1}$ \\ ${ }^{1}$ Federal State Budgetary Scientific Institution All-Russian Research Institute of Reclaimed Lands, Tver, Russia \\ Correspondence: G. Yu. Rabinovich, Federal State Budgetary Scientific Institution All-Russian Research \\ Institute of Reclaimed Lands, Tver 170530, Russia. E-mail: gur_u@mail.ru
}

Received: April 20, 2015 Accepted: May 20, 2015 Online Published: June 15, 2015

doi:10.5539/jas.v7n7p215 URL: http://dx.doi.org/10.5539/jas.v7n7p215

\begin{abstract}
A simulation experiment has shown that it is reasonable to use biologically active mixtures such as the liquid-phase biological products (LBP) as soil fertilizers. LBP produced by bioconversion of organic raw materials. The biological product in its composition contains a large quantity of the microflora, available phosphorus and potassium. On fine-grain soils demonstrated the greatest effect on LBP, which accumulate mobile biogenic components and show increasing biological parameters such as nitrogen soil mineralization and redox rate. The results of the regression analysis indicated strong relationships between individual values in different soils. It is significant that between $\mathrm{K}_{2} \mathrm{O}$ and $\mathrm{P}_{2} \mathrm{O}_{5}$ showed significant relationships for all soils. For fine-grain sod-podzol soils revealed consistently high and positive correlation coefficients between these indices. In fact, we observed a high stable level of responsiveness of these soils on the typical LBP indicators.
\end{abstract}

Keywords: soil, grain-size composition, liquid-phase biological products (LBP), composting, microorganisms, nutritive elements, reliable differences, regression analysis

\section{Introduction}

One of today's mainstream agricultural trends (agricultural methods) is to use less mineral fertilizers and more up-to-date bioproducts and - fertilizers to improve soil fertility (Prasad et al., 2015; Kumar et al., 2014). Current agricultural technologies can provide both high-quality, environmentally safe agricultural products and less contaminated environment (Platonycheva, 2009; Chintala et al., 2013, 2014). The bacteria inserted into the soil with the bioproducts multiply actively and work, enriching the soil with nutrients and acting favorably on the natural microorganisms promoting mineralization of the soil's organic materials and forming a favorable background for plant growth (Gil et al., 2008; Rajesh et al., 2003).

Investigations conducted at All-Russian Research Institute of Reclaimed Lands (VNIIMZ) led to creating two types of original-composition bioproducts: $\mathrm{LBP}^{\mathrm{A}}$ and $\mathrm{LBP}^{\mathrm{FGW}}$ (Rabinovich et al., 2007). Both products have the same input components and technologies but different fermentation stimulators: deciduous tree ashes and flour-grinding wastes in $\mathrm{LBP}^{\mathrm{A}}$ and $\mathrm{LBP}^{\mathrm{FGW}}$, respectively. Externally, LBPs are solutions containing 3\% or less of dry materials and giving nearly no sediment in setting. Their acidity is very favorable - alkalescent, 8.0 or lowers (Rabinovich et al., 2009). Analyses of the composition and properties of these bioproducts showed they were highly biogenic, physiological and nutritive - to be widely used in national economy. One of the key aspects of using the LBP is introducing them as microbiological fertilizers into practical agriculture. The objective of this work is to study the reasonability of using different LBPs on different-grain-size sod-podzol soils by monitoring of their nutritive elements and salt content dynamics.

\section{Method}

For this purpose, we have developed a composting experiment to produce soils of different grain size: sand, sandy-loam, light-loam and medium-loam. The initial soil properties were:

1) Sand soil: $\mathrm{pH}-4.81$; Humic acids (HA) $-3.05 \mathrm{mg}$ eq/100 g; $\mathrm{S}-2.51 \mathrm{mg}$ eq/100g; $\mathrm{P}_{2} \mathrm{O}_{5}-48.8 \mathrm{mg} / 100 \mathrm{~g} ; \mathrm{K}_{2} \mathrm{O}$ $-6.4 \mathrm{mg} / 100 \mathrm{~g} ; \mathrm{N}_{-} \mathrm{NO}_{3}{ }^{-}-0.78 \mathrm{mg} / 100 \mathrm{~g} ; \mathrm{N}^{-} \mathrm{NH}_{4}{ }^{+}-1.8 \mathrm{mg} / 100 \mathrm{~g} ; \mathrm{C}-1.14 \%$; fungi -3.19 thousand/g; phosphate mobilizers -0.8 million $/ \mathrm{g}$; mineralization coefficient $(\mathrm{MC})-3.5$;

2) Sandy-loam soil: $\mathrm{pH}-5.65 ; \mathrm{HA}-2.57 \mathrm{mg}$ eq/100 g; $\mathrm{S}-8.57 \mathrm{mg}$ eq/100g; $\mathrm{P}_{2} \mathrm{O}_{5}-86.5 \mathrm{mg} / 100 \mathrm{~g} ; \mathrm{K}_{2} \mathrm{O}-15.5$ $\mathrm{mg} / 100 \mathrm{~g} ; \mathrm{N}^{-N_{3}}{ }^{-}-1.88 \mathrm{mg} / 100 \mathrm{~g} ; \mathrm{N}^{-N_{4}}{ }^{+}-2.4 \mathrm{mg} / 100 \mathrm{~g} ; \mathrm{C}-1.9 \%$; fungi -1.41 thousand/g; phosphate 
mobilizers - 1.8 million/g; $\mathrm{MC}-3.1$;

3) Light-loam soil: $\mathrm{pH}-4.93 ; \mathrm{HA}-3.05 \mathrm{mg}$ eq/100 g; $\mathrm{S}-4.53 \mathrm{mg}$ eq/100g; $\mathrm{P}_{2} \mathrm{O}_{5}-28.2 \mathrm{mg} / 100 \mathrm{~g} ; \mathrm{K}_{2} \mathrm{O}-8.2$ $\mathrm{mg} / 100 \mathrm{~g} ; \mathrm{N}^{-N_{3}}{ }^{-}-2.0 \mathrm{mg} / 100 \mathrm{~g} ; \mathrm{N}^{-} \mathrm{NH}_{4}{ }^{+}-2.3 \mathrm{mg} / 100 \mathrm{~g} ; \mathrm{C}-1.4 \%$; fungi -1.41 thousand/g; phosphate mobilizers - 1.5 million/g; $\mathrm{MC}-7.5$;

4) Medium-loam soil: $\mathrm{pH}-5.85 ; \mathrm{HA}-1.74 \mathrm{mg}$ eq/100 g; $\mathrm{S}-12.11 \mathrm{mg}$ eq/100 g; $\mathrm{P}_{2} \mathrm{O}_{5}-38.7 \mathrm{mg} / 100 \mathrm{~g} ; \mathrm{K}_{2} \mathrm{O}-$ $9.3 \mathrm{mg} / 100 \mathrm{~g} ; \mathrm{N}^{-N}{ }_{3}{ }^{-}-2.47 \mathrm{mg} / 100 \mathrm{~g} ; \mathrm{N}^{-N_{H}}{ }^{+}-3.6 \mathrm{mg} / 100 \mathrm{~g} ; \mathrm{C}-1.8 \%$; fungi -0.96 thousand/g; phosphate mobilizers - 2.2 million/g; $\mathrm{MC}-20.0$.

Placed in plastic boxes naturally moistened soil samples weighing $250 \mathrm{~g}$. By calculation, each sample's moisture was adjusted to the field one optimum for the sod-podzol soil. We used the following basic fertilizers: peat (P), straw mixed with carbamide $(\mathrm{S}+\mathrm{C})$ and multipurpose compost (MPC) - equivalent in nitrogen doses (these will then be used abbreviations). References used no liquid-phase bioproducts. Table 1 shows the experiment design. LBP dose $\left(0.4 \mathrm{l} / \mathrm{m}^{2}\right)$ was chosen experimentally from a series of doses $\left(0.1-1.0 \mathrm{l} / \mathrm{m}^{2}\right)$ tested on the sandy-loam sod-podzol soil in a micro-field experiment. The experiment used a process LBP solution in concentration 1:30. The soil sample boxes were thermostated at $\mathrm{t}=22{ }^{\circ} \mathrm{C}$ for three months. At the beginning, middle and end of composting were sampled, all samples for planned analysis.

A set of physicochemical and microbiological parameters (Zvyagintsev, 1991; Russian State Standards (GOSTs 26483-85, 26489-85, 26951-86, 54650-2011, 26213-91) was evaluated in the samples selected. Microsoft Excel and Stat graphics Centurion software were used for processing the data. Statistical analysis was carried out on two criteria:

1) Evaluated the significance of differences between the values obtained for each indicator in the dynamics of the composting process (definition of a significance level " $p$ ");

2) Identify the relationship between the indicators (regression analysis - regression equations and correlation coefficient R).

Table 1. Experiment design

\begin{tabular}{|c|c|c|c|}
\hline \multirow{2}{*}{ Soil } & \multicolumn{3}{|c|}{ Basic fertilizer } \\
\hline & Peat (P) & Straw + Carbamide $(\mathrm{S}+\mathrm{C})$ & Multipurpose compost (MPC) \\
\hline \multirow[t]{3}{*}{ Sand } & $+\mathrm{LBP}^{\mathrm{A}}$ & $+\mathrm{LBP}^{\mathrm{A}}$ & $+\mathrm{LBP}^{\mathrm{A}}$ \\
\hline & $+\mathrm{LBP}^{\mathrm{FGW}}$ & $+\mathrm{LBP}^{\mathrm{FGW}}$ & $+\mathrm{LBP}^{\mathrm{FGW}}$ \\
\hline & Reference & Reference & Reference \\
\hline \multirow[t]{3}{*}{ Sandy-loam } & $+\mathrm{LBP}^{\mathrm{A}}$ & $+\mathrm{LBP}^{\mathrm{A}}$ & $+\mathrm{LBP}^{\mathrm{A}}$ \\
\hline & $+\mathrm{LBP}^{\mathrm{FGW}}$ & $+\mathrm{LBP}^{\mathrm{FGW}}$ & $+\mathrm{LBP}^{\mathrm{FGW}}$ \\
\hline & Reference & Reference & Reference \\
\hline \multirow[t]{3}{*}{ Light-loam } & $+\mathrm{LBP}^{\mathrm{A}}$ & $+\mathrm{LBP}^{\mathrm{A}}$ & $+\mathrm{LBP}^{\mathrm{A}}$ \\
\hline & $+\mathrm{LBP}^{\mathrm{FGW}}$ & $+\mathrm{LBP}^{\mathrm{FGW}}$ & $+\mathrm{LBP}^{\mathrm{FGW}}$ \\
\hline & Reference & Reference & Reference \\
\hline \multirow[t]{3}{*}{ Medium-loam } & $+\mathrm{LBP}^{\mathrm{A}}$ & $+\mathrm{LBP}^{\mathrm{A}}$ & $+\mathrm{LBP}^{\mathrm{A}}$ \\
\hline & $+\mathrm{LBP}^{\mathrm{FGW}}$ & $+\mathrm{LBP}^{\mathrm{FGW}}$ & $+\mathrm{LBP}^{\mathrm{FGW}}$ \\
\hline & Reference & Reference & Reference \\
\hline
\end{tabular}

\section{Results and Discussion}

The reaction of the different soils under study on LBP was evaluated through generalized biological parameters such as mineralization coefficients. The nitrogen mineralization coefficient (MC) is a standardized number of microorganisms feeding on mineral nitrogen versus the number of bacteria using organic nitrogen.

The sand soil (Figure 1a) showed the maximum average total MC when adding LBP of any type to the $\mathrm{S}+\mathrm{C}$ soil (average increase was 73\%). The P soils generally showed higher mineralization than the MPC ones.

The sandy-loam soil showed the LBP effect in practically all variants. Especially effective was $\mathrm{LBP}^{\mathrm{A}}$ with $\mathrm{S}+\mathrm{C}$ (63\% higher mineralization), whereas $\mathrm{LBP}^{\mathrm{FGW}}$ had a negative effect and lowered MC, but $\mathrm{LBP}^{\mathrm{FGW}}$ with $\mathrm{MPC}$ produced approximately three times higher nitrogen mineralization. 
The light-loam soil showed noticeable effect on mineralization level on both $\mathrm{P}$ and MPC soils for $\mathrm{LBP}^{\mathrm{FGW}}$ only. The $\mathrm{S}+\mathrm{C}$ soil showed no LBP effect at all (the reference level was the top in the light loams). The medium-loam soil with each fertilizer (Figure 1b) showed no mineralization increase for each LBP type.

Generally, LBP caused a higher nitrogen mineralization level mostly in fine-grain soils such as sand and sandy-loam because those soils initially had lower MC and lower accessible nitrogen content. That is why the nitrogen mobilization was inevitable in those soils.

At the same time, the soil reaction on different LBPs was analyzed by redox rate (RR) evaluation (the redox rate is catalase versus dehydrogenase arbitrary-unit activity actually reflecting the intensity of general biological breakup and synthesis).

LBP $^{\mathrm{A}}$ increased sand soil's RR for all soil fertilizers, especially effectively on $\mathrm{P}$ soils (RR grew by $67 \%$ ). $\mathrm{LBP}^{\mathrm{FGW}}$ was effective among sand soils with MPC only: $\mathrm{LBP}^{\mathrm{FGW}}$ increased RR by $78 \%, \mathrm{LBP}^{\mathrm{A}}$ with MPC increased RR approximately twice. However, not all the other soils showed this effect.

Consequently, the redox processes in the sand soil (featuring the lowest initial content of total carbon $=1.14 \%$ ) proved to be the most sensitive to LBP. As well as for the mineralization coefficient (MC), in the poorest sandy soil intensified all processes - to accumulate nutritive elements there.

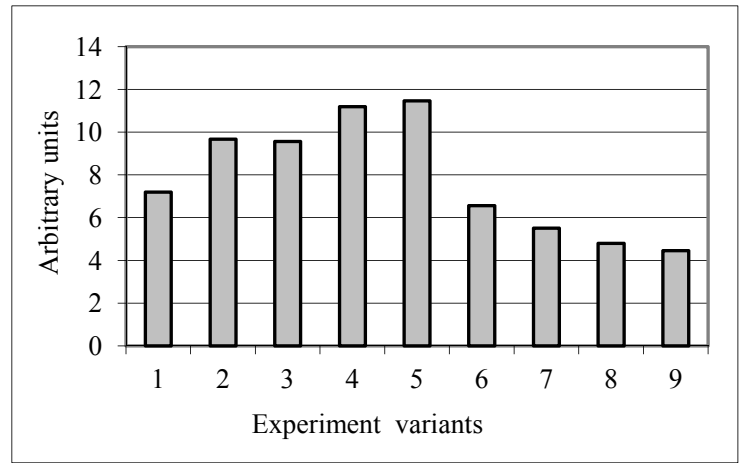

a

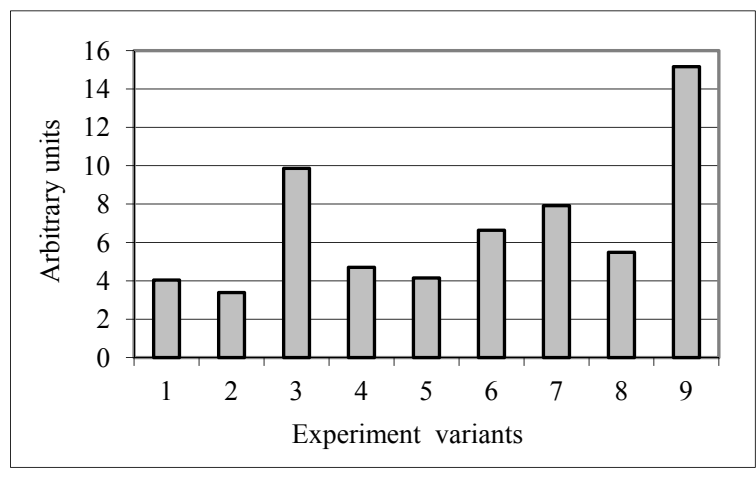

b

Figure 1. Average total mineralization coefficient (MC) in composting a sand (a) and medium-loam (b) soil: 1 $\mathrm{P}+\mathrm{LBP}^{\mathrm{A}} ; 2-\mathrm{P}+\mathrm{LBP}^{\mathrm{FGW}} ; 3-\mathrm{P} ; 4-\mathrm{S}+\mathrm{C}+\mathrm{LBP}^{\mathrm{A}} ; 5-\mathrm{S}+\mathrm{C}+\mathrm{LBP}^{\mathrm{FGW}} ; 6-\mathrm{S}+\mathrm{C} ; 7-\mathrm{MPC}+\mathrm{LBP}^{\mathrm{A}} ; 8-$ $\mathrm{MPC}+\mathrm{LBP}^{\mathrm{FGW}} ; 9-\mathrm{MPC}$

The analysis of individual microorganism groups quite often shows a high reliable increase in their number compared to the reference. Therefore, the sand soil shows a reliable rise in the number of nitrogen-transforming microorganism (ammonifiers) - by 3.12 million/g $(48 \%), p<0.001$, in the middle of the composting with the $\mathrm{P}$ soil and $\mathrm{LBP}^{\mathrm{A}}$, that continued until the experiment end. Also, we observed a reliable rise in the number of amylolytic microorganisms: by 10.07 million/g $(44 \%), \mathrm{p}<0.05$ in the beginning of composting with $\mathrm{MPC}+\mathrm{LBP}^{\mathrm{A}}$, by 20.4 million/g $(37 \%), \mathrm{p}<0.05$ in the middle of the process with $\mathrm{P}+\mathrm{LBP}^{\mathrm{FGW}}$, and by the average of 29.4 million/g $(32 \%), \mathrm{p}<0.05$ with $\mathrm{S}+\mathrm{C}$ and each LBP type.

The sandy-loam soil showed a noticeably more frequent reliable increase in the number of individual microorganism groups. So, the ammonifying microorganisms increase was observed in the beginning of composting for $\mathrm{P}+\mathrm{LBP}^{\mathrm{A}}(2.07$ million/g $(60 \%), \mathrm{p}<0.001), \mathrm{P}+\mathrm{LBP}^{\mathrm{FGW}}(2.64$ million/g $(66 \%), \mathrm{p}<0.01)$ and $\mathrm{MPC}+\mathrm{LBP}^{\mathrm{A}}(2.43$ million/g $(59 \%), \mathrm{p}<0.01), \mathrm{MPC}+\mathrm{LBP}^{\mathrm{FGW}}(0.59$ million/g $(26 \%), \mathrm{p}<0.05)$. This group of microorganisms showed no reliable increase in number in the middle of composting. Again, a reliable rise in the number of the ammonifying microorganisms in the sandy-loam soil was revealed at the end of composting with MPC, with either $\mathrm{LBP}^{\mathrm{A}}-3.7$ million/g (51\%), $\mathrm{p}<0.01$, or $\mathrm{LBP}^{\mathrm{FGW}}-1.88$ million/g $(34 \%), \mathrm{p}<0.05$.

A reliable rise in the number of amylolytic microorganisms was observed in the beginning of composting the sandy-loam soil for each LBP type:

1) With $\mathrm{P}-16.48$ million/g (72\%), $\mathrm{p}<0.05$ for $\mathrm{LBP}^{\mathrm{A}}$ and 25.94 million/g $(80 \%), \mathrm{p}<0.01$ for $\mathrm{LBP}^{\mathrm{FGW}}$;

2) With MPC -6.37 million/g (52\%), p $<0.001$ for $\mathrm{LBP}^{\mathrm{A}}$ and 19.56 million/g $(77 \%), \mathrm{p}<0.001$ for $\mathrm{LBP}^{\mathrm{FGW}}$;

3) As well as $\mathrm{LBP}^{\mathrm{A}}$ with $\mathrm{S}+\mathrm{C}-49.84$ million/g $(44 \%)$, p $<0.01$. 
In the middle of composting, a reliable increase in the number of amylolytic microorganisms in the sandy-loam soil was found with $\mathrm{P}+\mathrm{LBP}^{\mathrm{A}}$ (32.38 million/g (50\%), $\left.\mathrm{p}<0.05\right), \mathrm{P}+\mathrm{LBP}^{\mathrm{FGW}}$ (34.36 million/g (52\%), $\left.\mathrm{p}<0.05\right)$, and with $\mathrm{S}+\mathrm{C}$ and $\mathrm{MPC}$ for $\mathrm{LBP}^{\mathrm{FGW}}$ only -19.03 million/g $(19 \%), \mathrm{p}<0.05$ and 42.13 million/g $(61 \%), \mathrm{p}<0.01$ respectively. At the end of composting, there was a reliable increase in the number of amylolytic microorganisms for $\mathrm{P}+\mathrm{LBP}^{\mathrm{FGW}}$ and $\mathrm{S}+\mathrm{C}+\mathrm{LBP}^{\mathrm{A}}$.

The light-loam soil showed a reliable decrease in the number of ammonifying microorganisms for each LBP type, with $\mathrm{P}$ (excluding $\mathrm{LBP}^{\mathrm{FGW}}$ in the middle of composting) and with MPC (excluding $\mathrm{LBP}^{\mathrm{FGW}}$ at the end of composting). The light-loam soil showed a reliable rise in the number of amylolytic microorganisms in many cases:

1) In the beginning of composting with $\mathrm{P}+\mathrm{LBP}^{\mathrm{FGW}}-$ by 9.3 million/g $(35 \%), \mathrm{p}<0.01$;

2) In the middle of composting with $\mathrm{P}+\mathrm{LBP}^{\mathrm{A}}-$ by 19.19 million $/ \mathrm{g}(66 \%), \mathrm{p}<0.01$;

3) At the finish of the process with $\mathrm{P}+\mathrm{LBP}^{\mathrm{FGW}}-$ by 13.59 million/g $(79 \%), \mathrm{p}<0.001$ and $\mathrm{P}+\mathrm{LBP}^{\mathrm{FGW}}-5.75$ million/g $(62 \%), \mathrm{p}<0.01$.

Individual groups of microorganisms showed a very active growth in the middle-loam composting with LBP. Each LBP showed a reliable increase in the number of ammonifiers with P $(1.89$ million/g $(47 \%), \mathrm{p}<0.05$ for $\mathrm{LBP}^{\mathrm{A}}$, and $\mathrm{LBP}^{\mathrm{FGW}}-16.22$ million/g $\left.(88 \%), \mathrm{p}<0.01\right)$ and with MPC (by 74 million/g $(51 \%), \mathrm{p}<0.05$ for LBP ${ }^{\mathrm{A}}$, and $\mathrm{LBP}^{\mathrm{FGW}}-7.05$ million/g $\left.(81 \%), \mathrm{p}<0.01\right)$.

In the middle of composting, the medium-loam soil showed a reliable rise in the number of ammonifying microorganisms with each of LBP types:

1) With $\mathrm{S}+\mathrm{C}$ (by 2.52 million/g (22\%), $\mathrm{p}<0.05$ for $\mathrm{LBP}^{\mathrm{A}}$ and by 6.41 million $/ \mathrm{g}(41 \%), \mathrm{p}<0.05$ for $\mathrm{LBP}^{\mathrm{FGW}}$ );

2) With MPC (by 1.35 million/g (31\%), p $<0.05$ for $\mathrm{LBP}^{\mathrm{A}}$ and by 2.76 million/g (48\%), $\mathrm{p}<0.01$ for $\mathrm{LBP}^{\mathrm{FGW}}$ ).

At the finish of composting, a reliable increase in the number of ammonifiers in the soil was from $\mathrm{LBP}^{\mathrm{A}}$ :

1) With P, by 4.07 million/g $(49 \%), \mathrm{p}<0.01$;

2) With $\mathrm{S}+\mathrm{C}$, by 6.05 million/g $(43 \%), \mathrm{p}<0.01$, whereas $\mathrm{LBP}^{\mathrm{FGW}}$;

3) With $\mathrm{P}$ gave the rise by 2.87 million/g (41\%), p $<0.05$ and by 3.06 million/g $(27 \%)$, p $<0.05$ with $\mathrm{S}+\mathrm{C}$.

In the beginning of composting of the medium-loam soil, a reliable increase in the number of amylolytic microorganisms was found only for $\mathrm{P}+\mathrm{LBP}^{\mathrm{FGW}}$, by 19.2 million $/ \mathrm{g}(32 \%), \mathrm{p}<0.05$. At the end of the composting, there were a greater number of amylolytic microorganisms in all variants with $\mathrm{LBP}$, except $\mathrm{S}+\mathrm{C}+\mathrm{LBP}^{3}$ :

1) For the background of $\mathrm{T}$ : + reference of 3.73 million/g (23\%) with $\mathrm{LBP}^{\mathrm{A}}, \mathrm{p}<0.05$, and $10.0 \mathrm{million} / \mathrm{g}(44 \%)$, $\mathrm{p}<0.05$ with $\mathrm{LBP}^{\mathrm{FGW}}$;

2) For the background of $\mathrm{S}+\mathrm{C}+\mathrm{LBP}^{\mathrm{FGW}}:+$ reference of 16.17 million $/ \mathrm{g}(39 \%), \mathrm{p}<0.05$;

3) For the background of MPC: + reference of 3.85 million/g (33\%) with $\mathrm{LBP}^{\mathrm{A}}, \mathrm{p}<0.05$, and $\mathrm{LBP}^{\mathrm{FGW}}-18.44$ million/g $(70 \%), \mathrm{p}<0.01$.

Phosphate-mobilizing microorganisms showed interesting dynamics confirming substantial differences in reaction of different soils to LBPs. There was a reliable growth in the number of phosphate mobilizers in the sand soil in the beginning of composting with $\mathrm{P}$ (by 2.33 million $/ \mathrm{g}(55 \%) \mathrm{p}<0.001$ for $\mathrm{LBP}^{\mathrm{A}}$ and by 2.0 million/g $(52 \%) \mathrm{p}<0.001$ for $\left.\mathrm{LBP}^{\mathrm{FGW}}\right)$ - see Figure 2, a. At the finish of composting, the number of phosphate mobilizers grew for MPC $+\mathrm{LBP}^{\mathrm{A}}$ by 1.12 million $/ \mathrm{g}(42 \%), \mathrm{p}<0.05$.

The sandy-loam soil showed the best growth of the phosphate mobilizers with the bio product based on FGW, both for P and MPC. Every background of the basic fertilizer showed the growth of the microorganisms of this group in the beginning of composting:

1) For the background of $\mathrm{P}-2.68$ million/g (87\%), $\mathrm{p}<0.05$ with $\mathrm{LBP}^{\mathrm{A}}$ and 4.2 million/g $(92 \%), \mathrm{p}<0.001$ with $\mathrm{LBP}^{\mathrm{FGW}}$;

2) For the background of $\mathrm{S}+\mathrm{C}-0.48$ million/g (10\%), $\mathrm{p}<0.05$ with $\mathrm{LBP}^{\mathrm{A}}$ and 2.66 million/g $(39 \%)$ for $\mathrm{p}<$ 0.001 with $\mathrm{LBP}^{\mathrm{FGW}}$;

3) For the background of MPC, the average increase for each bioproducts was 3.64 million/g (69\%), $p<0.001$.

The end of the experiment showed a reliable increase in the number of the microorganisms mobilizing organic phosphates in the sandy-loam soil with $\mathrm{P}+\mathrm{LBP}^{\mathrm{FGW}}-9.76$ million $/ \mathrm{g}(74 \%), \mathrm{p}<0.01$, as well as with $\mathrm{S}+\mathrm{C}+\mathrm{LBP}^{\mathrm{A}}-$ 5.05 million/g $(59 \%), \mathrm{p}<0.01$. 
The effect of LBP on the development of the phosphate mobilizers in the light-loam soil occurred only for the $\mathrm{S}+\mathrm{C}$ background, with each of the LBPs. A reliable increase in the number of the microorganisms was found in variants $\mathrm{S}+\mathrm{C}+\mathrm{LBP}^{\mathrm{FGW}}(3.04$ million/g $(47 \%) \mathrm{p}<0.01)$ in the beginning of composting, and $\mathrm{S}+\mathrm{C}+\mathrm{LBP}{ }^{\mathrm{A}}(6.22$ million/g $(31 \%) \mathrm{p}<0.05)$ in the middle of the process. The end of composting showed a reliable decrease in the number of microorganism of this group in every variant of using the bioproducts.

A reliable growth of the number of the microorganisms mobilizing organic phosphates in the medium-loam soil (Figure 2,b) occurred only at the end of composting with $\mathrm{P}+\mathrm{LBP}^{\mathrm{FGW}}-1.14$ million/g $(22 \%), \mathrm{p}<0.05$, as well as for each bioproducts with MPC: 2.82 million/g (40\%), $\mathrm{p}<0.05$ with $\mathrm{LBP}^{\mathrm{A}}$, and with $\mathrm{LBP}^{\mathrm{FGW}}-$ almost 2.0 $(32 \%), \mathrm{p}<0.01$.

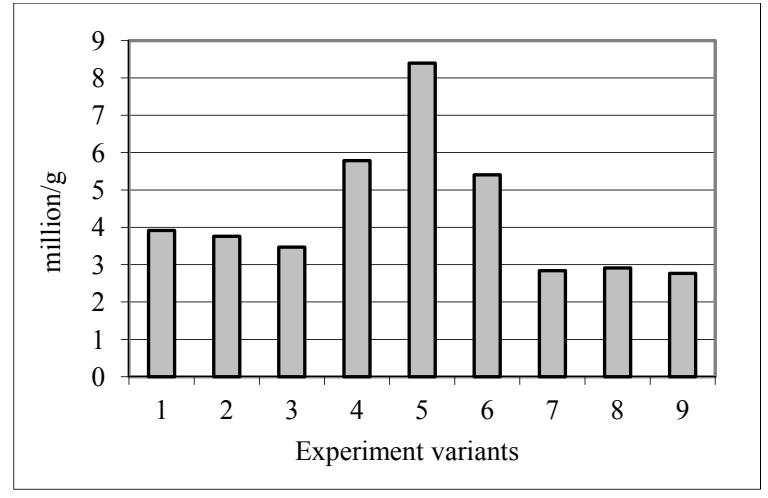

a

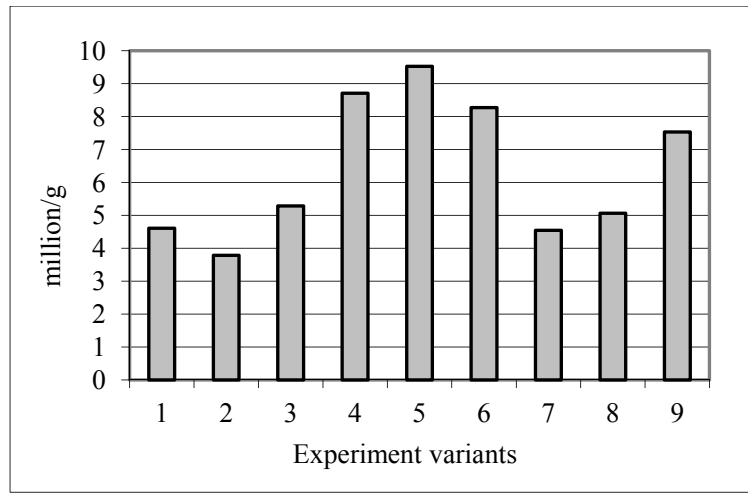

b

Figure 2. Average total content of phosphate-mobilizing microorganisms throughout the entire composting of the sand (a) and medium-loam (b) soil: $1-\mathrm{P}+\mathrm{LBP}^{\mathrm{A}} ; 2-\mathrm{P}+\mathrm{LBP}^{\mathrm{FGW}} ; 3-\mathrm{P} ; 4-\mathrm{S}+\mathrm{C}+\mathrm{LBP}^{\mathrm{A}} ; 5-\mathrm{S}+\mathrm{C}+\mathrm{LBP}^{\mathrm{FGW}} ; 6-$ $\mathrm{S}+\mathrm{C} ; 7-\mathrm{MPC}+\mathrm{LBP}^{\mathrm{A}} ; 8-\mathrm{MPC}+\mathrm{LBP}^{\mathrm{FGW}} ; 9-\mathrm{MPC}$

Therefore, the most favorable conditions for soil microorganism activation were in the sandy-loam soil, which is confirmed by the frequency of the results suggesting a reliable increase in the microbiological parameters for the LBP variants over the reference. Because of the similar humus content in the sandy-loam and middle-loam soils, the frequency of reliable increases in the microbiological parameters of the latter was quite high too.

Observations on the dynamics of nutritive elements accumulation in the soils suggested that it was different from the increase in the number of individual microorganisms. The active accumulation of the nutritive elements occurred in low-humus soils, especially in the sandy one. The accumulation of mobile phosphates in the sandy soil in the course of composting was the maximum for each of LBP types with every background fertilizers. A reliable rise of phosphorus was observed with $\mathrm{LBP}^{\mathrm{A}}$ in the middle and at the end of composting. It was 3.4; 7.2; 6.5 - in the middle of the process and $7.7 ; 3.5 ; 2.6$ - at the end $(\mathrm{mg} / 100 \mathrm{~g}$ of soil, corresponding to $\mathrm{P}, \mathrm{S}+\mathrm{C}$, and MPC, $\mathrm{p}<0.01$ or $\mathrm{p}<0.001)$. The same periods for $\mathrm{LBP}^{\mathrm{FGW}}$ showed reliable differences for $\mathrm{S}+\mathrm{C}$ only - the increase was 8.4 and $3.1 \mathrm{mg} / 100 \mathrm{~g}$ of soil $(\mathrm{p}<0.001)$.

The sandy-loam soil showed the maximum positive effect in phosphate accumulation with each LBP and MPC. There was a reliable rise in the middle and end of composting, with an average increase over reference about 8.9 $\mathrm{mg} / 100 \mathrm{~g}(\mathrm{p}<0.01$ in the middle) and $2.7 \mathrm{mg} / 100 \mathrm{~g}(\mathrm{p}<0.05$ at the end $)$.

The light-loam soil showed high $\mathrm{P}_{2} \mathrm{O}_{5}$ when LBP was used with every background fertilizer, the maximum LBP effect occurred with background $\mathrm{S}+\mathrm{C}$ (average $\mathrm{P}_{2} \mathrm{O}_{5}$ increase over reference about 9\%). The light-loam soil composting gave a reliable $\mathrm{P}_{2} \mathrm{O}_{5}$ increase in many variants:

1) Beginning: $\mathrm{P}+\mathrm{LBP}^{\mathrm{A}}(1.8 \mathrm{mg} / 100 \mathrm{~g}, \mathrm{p}<0.01), \mathrm{S}+\mathrm{C}+\mathrm{LBP}^{\mathrm{FGW}}(2.0 \mathrm{mg} / 100 \mathrm{~g}, \mathrm{p}<0.01)$;

2) Middle: $\mathrm{P}+\mathrm{LBP}^{\mathrm{A}}(2.0 \mathrm{mg} / 100 \mathrm{~g}, \mathrm{p}<0.05), \mathrm{S}+\mathrm{C}$ with each LBP type showed an average increase of 2.2 $\mathrm{mg} / 100 \mathrm{~g}\left(\mathrm{LBP}^{\mathrm{A}}, \mathrm{p}<0.05, \mathrm{LBP}^{\mathrm{FGW}}, \mathrm{p}<0.01\right), \mathrm{MPC}+\mathrm{LBP}^{\mathrm{FGW}}-8.5 \mathrm{mg} / 100 \mathrm{~g}, \mathrm{p}<0.001$;

3) End: $\mathrm{S}+\mathrm{C}+\mathrm{LBP}^{\mathrm{A}}(5.1 \mathrm{mg} / 100 \mathrm{~g}, \mathrm{p}<0.01)$, MPC with each LBP type showed an average increase of 1.6 $\mathrm{mg} / 100 \mathrm{~g}, \mathrm{p}<0.01$ and $\mathrm{p}<0.05$.

The middle-loam soil reacted to LBP with a lower $\mathrm{P}_{2} \mathrm{O}_{5}$ accumulation, compared to the other soils studied. The maximum LBP effect was shown with $\mathrm{S}+\mathrm{C}$ background ( $4 \%$ above the reference). In the beginning of 
composting, a reliable increase in mobile phosphorus compounds was found only with $\mathrm{S}+\mathrm{C}+\mathrm{LBP} \mathrm{P}^{\mathrm{A}}(1.6 \mathrm{mg} / 100$ $\mathrm{g}, \mathrm{p}<0.05)$, at the end of composting - with $\mathrm{S}+\mathrm{C}+\mathrm{LBP}^{\mathrm{FGW}}(2.8 \mathrm{mg} / 100 \mathrm{~g}, \mathrm{p}<0.01)$, and with $\mathrm{P}+\mathrm{LBP} \mathrm{A}^{\mathrm{A}}(2.3$ $\mathrm{mg} / 100 \mathrm{~g}, \mathrm{p}<0.01)$.

Research the content of mobile forms of potassium in the soil is not possible to detect the same as that of the active growth of mobile phosphorus. The sand soil showed the maximum effect of $\mathrm{LBP}^{\mathrm{A}}$ and $\mathrm{LBP}{ }^{\mathrm{FGW}}$ on $\mathrm{S}+\mathrm{C}$ (average rise over reference was $5.5 \mathrm{mg} / 100 \mathrm{~g}(11 \%), \mathrm{p}<0.01)$. The sandy-loam soil showed a slight effect of each LBP for both $\mathrm{P}$ and $\mathrm{MPC}$, so that a reliable $\mathrm{K}_{2} \mathrm{O}$ increase was found only in the beginning of composting, $\mathrm{P}+\mathrm{LBP}^{\mathrm{FGW}}-0.9 \mathrm{mg} / 100 \mathrm{~g}, \mathrm{p}<0.01$. A noticeable reliable $\mathrm{K}_{2} \mathrm{O}$ increase caused by $\mathrm{LBP}^{\mathrm{FGW}}$ was observed in the light-loam soil, in the middle of composting with $\mathrm{S}+\mathrm{C}$ (by $8.6 \mathrm{mg} / 100 \mathrm{~g}(10 \%), \mathrm{p}<0.001)$ and MPC (by 8.6 $\mathrm{mg} / 100 \mathrm{~g}(7 \%), \mathrm{p}<0.001)$, whereas $\mathrm{P}$ background had a lower effect. At the end of the light-loam soil composting, we observed a reliable $\mathrm{K}_{2} \mathrm{O}$ rise over reference in case of $\mathrm{S}+\mathrm{C}+\mathrm{LBP}{ }^{\mathrm{A}}-0.9 \mathrm{mg} / 100 \mathrm{~g}, \mathrm{p}<0.01$. The medium-loam soil showed no LBP effect on mobile potassium accumulation for each background fertilizer.

All soils under study demonstrated a trend of nitrate nitrogen accumulation in the course of composting. In all cases, the effect lowered depending on the background fertilizer used $\mathrm{S}+\mathrm{C}>\mathrm{MPC}>\mathrm{T}$. For example, the sandy-loam soil showed a more noted nitrogen accumulation effect with S+C and MPC (10-12\%) versus $8 \%$.

Along with the analysis of the results on individual physicochemical and microbiological parameters, we tried to reveal pair relationships among some of them by regression analysis. Revealing such relationships allowed evaluating the degree of influence / correlation between the factors under analysis.

In our case, the regression analysis was aimed at revealing the predominant factors shaping the nutritive value of individual soils. That is why only physicochemical parameters $\left(\mathrm{P}_{2} \mathrm{O}_{5}, \mathrm{~K}_{2} \mathrm{O}, \mathrm{NH}_{4}, \mathrm{NO}_{3}, \mathrm{pH}\right)$ were considered as an independent variable (y). All different soils showed strong correlation between contents of mobile phosphorus and potassium (Table 2), potassium and nitrate nitrogen (Table 3). Biological factors had an effect on shaping the nutritive element contents, but only in high carbon content soils - sandy-loam and middle-loam ones (Table 4).

The regression analysis suggests that the nutritive value in the medium-loam soil depends considerably on the living phase. That is why the nutritive element accumulation has a positive correlation to the number of amylolytic and phosphate-mobilizing microorganisms. However, a high number of soil microorganisms not always reflect the level of general biological activity of the soil. Actually, generalized parameters such as RR and $\mathrm{MC}$ can be considered as the measure of such activity. As noted above, the medium-loam soil had low RR. Thus, the regression analysis validated earlier conclusions that the medium-loam soil has a minimum need for the nutritive element increase, because it has initially the maximum MC providing the nutritive value of this soil. That is why the medium-loam soil is less sensitive to LBPs (an inhibited or delayed effect).

At the same time, accumulation of the nutritive value in the finer-grain soils is considerably caused by addition of accessible nutritive elements from background fertilizers and LBP. In this case, the regression analysis shows a close relationship of each variable analyzed (y) and dependent variables (x) which are the changing variables characterizing the soil nutrition values from different points of view. Therefore, it is quite natural that the sand soil gives the highest general biological parameters (MC and RR) reflecting active disintegration and synthesis, accumulating nutritive elements (especially mobile potassium and exchange phosphorus).

Table 2. Regression equations and correlation coefficients reflecting correlation between $\mathrm{P}_{2} \mathrm{O}_{5}$ and $\mathrm{K}_{2} \mathrm{O}$ in different soils

\begin{tabular}{lll}
\hline Soil & Regression equations & Correlation coeff. $\mathrm{R}$ \\
\hline Sand & $\mathrm{y}\left(\mathrm{P}_{2} \mathrm{O}_{5}\right)=39.9806+0.635922 \times\left(\mathrm{K}_{2} \mathrm{O}\right)$ & 0.67 \\
& $\mathrm{y}\left(\mathrm{K}_{2} \mathrm{O}\right)=-19.3971+0.700796 \times\left(\mathrm{P}_{2} \mathrm{O}_{5}\right)$ & 0.67 \\
\multirow{3}{*}{ Sandy-loam } & $\mathrm{y}\left(\mathrm{P}_{2} \mathrm{O}_{5}\right)=71.5904+0.801192 \mathrm{x}\left(\mathrm{K}_{2} \mathrm{O}\right)$ & 0.72 \\
& $\mathrm{y}\left(\mathrm{K}_{2} \mathrm{O}\right)=-34.03313+0.649865 \mathrm{x}\left(\mathrm{P}_{2} \mathrm{O}_{5}\right)$ & 0.72 \\
Light-loam & $\mathrm{y}\left(\mathrm{P}_{2} \mathrm{O}_{5}\right)=17.152+0.620334 \mathrm{x}\left(\mathrm{K}_{2} \mathrm{O}\right)$ & -0.70 \\
& $\mathrm{y}\left(\mathrm{K}_{2} \mathrm{O}\right)=\exp \left[1.1266+0.0568739 \times\left(\mathrm{P}_{2} \mathrm{O}_{5}\right)\right]$ & 0.67 \\
Medium-loam & $\mathrm{y}\left(\mathrm{P}_{2} \mathrm{O}_{5}\right)=21.569+1.13761 \times\left(\mathrm{K}_{2} \mathrm{O}\right)$ & -0.62 \\
& $\left(\mathrm{~K}_{2} \mathrm{O}\right)=\exp \left[1.29232+0.0320503 \times\left(\mathrm{P}_{2} \mathrm{O}_{5}\right)\right]$ & 0.62 \\
\hline
\end{tabular}


Table 3. Regression equations and correlation coefficients reflecting correlation between $\mathrm{K}_{2} \mathrm{O}$ and $\mathrm{NO}_{3}$ in different soils

\begin{tabular}{lll}
\hline Soil & Regression equations & Correlation coeff. R \\
\hline Sand & $\mathrm{y}\left(\mathrm{K}_{2} \mathrm{O}\right)=\exp \left[1.70028+0.113704 \mathrm{x}\left(\mathrm{NO}_{3}\right)\right]$ & 0.75 \\
& $\mathrm{y}\left(\mathrm{NO}_{3}\right)=2.67235+0.360577 \mathrm{x}\left(\mathrm{K}_{2} \mathrm{O}\right)$ & 0.71 \\
Sandy-loam & $\mathrm{y}\left(\mathrm{K}_{2} \mathrm{O}\right)=16.0306+0.992873 \mathrm{x}\left(\mathrm{NO}_{3}\right)$ & 0.57 \\
& $\mathrm{y}\left(\mathrm{NO}_{3}\right)=\exp \left[1.10486+0.0421392 \mathrm{x}\left(\mathrm{K}_{2} \mathrm{O}\right)\right]$ & 0.62 \\
Light-loam & $\mathrm{y}\left(\mathrm{NO}_{3}\right)=\exp \left[1.0821+0.0632953 \mathrm{x}\left(\mathrm{K}_{2} \mathrm{O}\right)\right]$ & 0.73 \\
Medium-loam & $\mathrm{y}\left(\mathrm{K}_{2} \mathrm{O}\right)=7.27885+0.56151 \mathrm{x}\left(\mathrm{NO}_{3}\right)$ & 0.58 \\
& $\mathrm{y}\left(\mathrm{NO}_{3}\right)=\exp \left[0.648518+0.109123 \mathrm{x}\left(\mathrm{K}_{2} \mathrm{O}\right)\right]$ & 0.64 \\
\hline
\end{tabular}

Table 4. Regression equations and correlation coefficients reflecting correlation between biological factors and nutritive element accumulation in different soils

\begin{tabular}{lll}
\hline Soil & Regression equations & Correlation coeff. R \\
\hline Sandy-loam & $\mathrm{y}\left(\mathrm{NO}_{3}\right)=14.3454-4.33651 \mathrm{x}(\mathrm{RR})$ & 0.53 \\
& $\mathrm{y}\left(\mathrm{NH}_{4}\right)=\exp [-1.07037+0.113452 \mathrm{x}($ ammonifying microbes $)]$ & 0.64 \\
& $\mathrm{y}\left(\mathrm{NH}_{4}\right)=0.514983+0.0618054 \mathrm{x}$ (phosphate mobilizers) & 0.52 \\
& $\mathrm{y}\left(\mathrm{K}_{2} \mathrm{O}\right)=8.86168+0.0556368 \mathrm{x}($ amylolytic microbes $)$ & 0.50 \\
Medium-loam & $\mathrm{y}\left(\mathrm{NO}_{3}\right)=4.76746+0.723627 \mathrm{x}($ phosphate mobilizers $)$ & 0.64 \\
& $\mathrm{y}\left(\mathrm{NH}_{4}\right)=0.638225+0.0968849 \mathrm{x}$ (phosphate mobilizers) & 0.44 \\
\hline
\end{tabular}

\section{Conclusion}

Thanks to LBP, the sod-podzol soils form a favorable background of nutritive elements accessible to the plants. Moreover, this process is most effective in poor (low-humus) soils and fine-grain soils. That is why using LBP for fine-grain soils (first of all, the sand soil) gives an immediate effect. LBP reliably elevates the mobile phosphorus and demonstrates the same favorable trend for other nutritive elements. Coarse-grain and humus-rich sod-podzol soils demonstrate a different LBP effect. They do not accumulate $\mathrm{P}_{2} \mathrm{O}_{5}$, but increase reliably the number of microorganisms of the widest variety of physiological groups. The sandy-loam and light-loam soils show no definite position within the soil series, because their organic material is substantially different. That is why the sandy-loam soil (total carbon $=1.9 \%$ ) sometimes shows features of the medium-loam one (total carbon $=1.8 \%$ ), and its reaction to LBP becomes unpredictable.

The results of the regression analysis indicated strong relationships between individual values in different soils. It is significant that between $\mathrm{K}_{2} \mathrm{O}$ and $\mathrm{P}_{2} \mathrm{O}_{5}$ showed significant relationships for all soils. For fine-grain sod-podzol soils revealed consistently high and positive correlation coefficients between these indices. In fact, we observed a high stable level of responsiveness of these soils on the typical LBP indicators.

Thus, this simulation experiment showed that it was reasonable to use LBP on fine-grain sod-podzol soils as an effective fertilizer.

\section{References}

Chintala, R., Mollinedo, J., Schumacher, T. E., Malo, D. D., Papiernik, S., Clay, D. E., ... Gulbrandson, D. W. (2013). Nitrate sorption and desorption by biochars produced from microwave pyrolysis. Microporous and Mesoporous Materials, 179, 250-257. http://dx.doi.org/10.1016/j.micromeso.2013.05.023

Chintala, R., Schumacher, T. E., McDonald, L. M., Clay, D. E., Malo, D. D., Clay, S. A., ... Julson, J. L. (2014). Phosphorus sorption and availability in biochars and soil biochar mixtures. CLEAN-Soil Air Water, 42(5), 626-634. http://dx.doi.org/10.1002/clen.201300089

Gil, T. A., Sokolova, M. G., \& Akimova, G. P. (2008). Bacterial Bioproducts Effect on the Soil Microorganisms. Plodorodie (Fertility), 4, 24-25. Retrieved from http://elibrary.ru/item.asp?id=12799674

Kumar, S., Nakajima, T., Mbonimpa, E. G., Gautam, S., Somireddy, U. R., Kadono, A., ... Fausey, N. (2014). 
Long-term tillage and drainage influences on soil organic carbon dynamics, aggregate stability, and carbon yield. Soil Science \& Plant Nutrition, 60(1), 108-118. http://dx.doi.org/10.1080/00380768.2013.878643

Platonycheva, Yu. N. (2009). Effect of Micromak and Bioproducts on Biological Activity of Gray Forest Soils. Plodorodie (Fertility), 3, 33-34. Retrieved from http://elibrary.ru/item.asp?id=13015179

Prasad, R., Hochmuth, G. J., \& Boote, K. J. (2015). Estimation of Nitrogen Pools in Irrigated Potato Production on Sandy Soil Using the Model SUBSTOR. PLoS ONE, 10(1), e0117891. http://dx.doi.org/10.1371/journal.pone.0117891

Rabinovich, G. Yu., Fomicheva, N. V., \& Smirnova, Yu. D. (2009). A method of Producing Liquid-phase Biological for Crop Production and Agriculture. Patent of the Russian Federation No. 2365568. Retrieved from http://bd.patent.su/2365000-2365999/pat/servl/servlet0798.html

Rabinovich, G. Yu., Kovalev, N. G., \& Fomicheva, N. V. (2007). A New Type of Biologically Active Products: Production, Composition, Application Prospects. Vestnik RASKhN (Bulletin of the Russian Academy of Agricultural Sciences), 3, 71-72. Retrieved from http://elibrary.ru/item.asp?id=9500480

Rajesh, C., Reddy, K. S., Naidu, M. V. S., \& Ramavataram, N. (2003). Production and evaluation of compost and vermicompost from solid organic wastes. Asian Journal of Microbiology, Biotechnology, and Environmental Science, 5, 307-311.

Russian State Standard GOST 26213-91 Soils. Methods for Organic Material Evaluation. Retrieved from http://vsegost.com/Catalog/10/10564.shtml

Russian State Standard GOST 26483-85 Soils. Salt Extract pH Evaluation by CINAO (Central Institute of Agrochemical Service) Method. Retrieved from http://vsegost.com/Catalog/29/29278.shtml

Russian State Standard GOST 26489-85 Soils. Exchange Ammonium Evaluation in Soils by CINAO (Central Institute of Agrochemical Service) Method. Retrieved from http://vsegost.com/Catalog/29/29115.shtml

Russian State Standard GOST 26951-86 Soils. Nitrates Evaluation in Soils by Ionometry. Retrieved from http://vsegost.com/Catalog/12/12344.shtml

Russian State Standard GOST 54650-2011 Soils. Mobile Phosphorus and Potassium Compounds Evaluation in Soils by Kirsanov Method Modified by CINAO. Retrieved from http://vsegost.com/Catalog/52/52221.shtml

Zvyagintsev, D. G. (1991). Methods in Soil Microbiology and Biochemistry (p. 303). Moscow, Russia: Moscow State University Publishers. Retrieved from http://www.pochva.com/?content=3\&book_id=0128

\section{Copyrights}

Copyright for this article is retained by the author(s), with first publication rights granted to the journal.

This is an open-access article distributed under the terms and conditions of the Creative Commons Attribution license (http://creativecommons.org/licenses/by/3.0/). 